\title{
PENGARUH METODE PEMBELAJARAN DAN MOTIVASI TERHADAP HASIL BELAJAR
}

\author{
Arsi Yulianjani ${ }^{1}$ \\ Dosen AMIK Raharja Informatika ${ }^{1}$ \\ Jl. Jendral Sudirman No. 40, Modern Cikokol, Tangerang ${ }^{1}$ \\ Email: arsiyulianjani@raharja.info ${ }^{1)}$
}

\begin{abstract}
ABSTRAK
Tujuan penelitian ini adalah untuk mengetahui pengaruh Metode Pembelajaran terhadap hasil belajar bahasa Inggris, untuk mengetahui pengaruh motivasi belajar terhadap hasil belajar bahasa Inggris, dan untuk mengetahui pengaruh metide pembelajaran dan Motivasi secara bersama-sama terhadap hasil belajar bahasa Inggris. Metode penelitian yang digunakan adalah metode eksperimen. Sampel sebanyak 80 siswa dipilih secara random dengan teknik acak sederhana. Pengumpulan data menggunakan instrumen tes. Analisis data menggunakan statistika deskriptif, koefisien korelasi ganda Pearson, koefisien determinasi korelasi dan analisa regresi. Uji statistik dipergunakan uji $t$ dan uji $F$. Penelitian ini dilaksanakan pada bulan April 2015 sampai Juni 2015. Hasil penelitian menunjukkan : (1) Terdapat pengaruh yang signifikan Metode Pembelajaran (X1) dan Motivasi (X2) secara bersamasama terhadap hasil belajar bahasa Inggris ( $Y$ )siswa siswi di SMK Negeri Tangerang. Hal tersebut dapat dibuktikan dengan nilai $F 0=4,219$ dan Sig. $=0,000<0,05$. (2)Terdapat pengaruh yang signifikan Metode Pembelajaran terhadap hasil belajar bahasa Inggris siswa siswi di SMK Negeri di Tangerang.Hal ini dibuktikan dengan perolehan Fo = 28,581 dan Sig. =0,000 $<0,05$. (3) Terdapat pengaruh yang signifikan motivasi belajar terhadap hasil belajar bahasa Inggris siswa siswi di SMK Negeri di Tangerang. Hal ini dibuktikan dengan perolehan $F_{O}=44,095$ dan sig. =0,000<0,05
\end{abstract}

\begin{abstract}
The purpose of this study is to determine the influence of Learning Method on English learning outcomes, to determine the effect of learning motivation on English learning outcomes, and to determine the influence of learning method and motivation together with the results of English learning. The research method uses experimental method. A sample of 80 students was selected randomly with a simple random technique. The data collection uses test instruments. The analysis of data uses descriptive statistics, Pearson's double correlation coefficient, Correlation of coefficient of determination and regression analysis. The statistical test uses $t$ test and $F$ test. This research was conducted on April 2015 until June 2015. The results showed: (1) There is a significant influence of Learning Method (X1) and Motivation (X2) together to the learning result of English (Y) students at SMK Negeri Tangerang. It can be proved by the value of $F 0=4,219$ and Sig. $=0,000<0.05$. (2) There is a significant influence of Learning Method on English learning result of students at SMK Negeri in Tangerang. This is proved by the acquisition of $F_{O}=28,581$ and Sig. $=0,000<0.05$. (3) There is a significant influence of learning motivation on English learning result of students at SMK Negeri in Tangerang. This is evidenced by the acquisition of Fo $=44.095$ and sig. $=0,000<0.05$
\end{abstract}

\section{A. PENDAHULUAN}

Di Indonesia, pendidikan merupakan program wajib pemerintah yang selalu mendapat perhatian khusus. Pemerintah selalu berusaha untuk meningkatkan kualitas pendidikan di Indonesia dan memberikan kesempatan bagi masyarakatnya untuk mendapatkan pendidikan yang lebih baik. Karena bangsa yang maju adalah bangsa yang dapat meningkatkan mutu pendidikannya. Dengan pendidikan, manusia dapat membuat suatu perubahan dan dapat 
mempelajari hal-hal baru. Pendidikan juga dapat membentuk watak dan kepribadian manusia untuk menjadi lebih baik. Hal tersebut tercantum dalam undang-undang pendidikan No. 20 tahun 2003 tentang Sistim Pendidikan Nasional:

"Pendidikan Nasional berfungsi mengembangkan kemampuan dan membentuk watak serta peradaban bangsa yang bermartabat dalam rangka mencerdaskan kehidupan bangsa, bertujuan untuk berkembangnya potensi peserta didik agar menjadi manusia yang beriman dan bertakwa kepada Tuhan Yang Maha Esa, berakhlak mulia, sehat berilmu, cakap, kreatif, mandiri dan menjadi warga Negara yang demokratis serta bertanggung jawab”.

Proses belajar mengajar merupakan proses timbal balik antar guru dan siswa untuk secara bersama mengusahakan pencapaian tujuan instruksional yang telah disusun oleh guru yang sebelumnya. Oleh karena itu usaha pencapaian skor yang tinggi sebagai wujud hasil belajar siswa bukan hanya tanggung jawab guru semata namun yang paling utama adalah tanggung jawab siswa dalam kesiapannya menerima dan mengembangkan ilmu yang diberikan guru dengan menunjukkan sikap dan motivasi yang positif terhadap bahasa dengan cara belajar yang baik yang dilandasi oleh minat dan motivasi yang cukup tinggi.

Kegiatan mengajarpun harus dibuat lebih menarik dengan bermacam-macam gaya belajar dan metode belajar yang menarik. Dengan demikian siswa akan lebih tertarik dan bersemangat untuk belajar dan tidak merasakan kebosanan. Dan prestasi belajarpun akan dapat dicapai secara optimal. Sumartini dan Usman (2000:74) mengatakan bahwa:

Salah satu tugas utama guru adalah menciptakan suasana dan atau iklim belajar mengajar yang dapat memotivasi siswa untuk senantiasa belajar dengan baik dan bersemangat. Dengan iklim belajar mengajar yang menantang berkompetisi secara sehat serta memotivasi siswa dalam belajar, akan berdampak positif dalam mencapai hasil prestasi belajar yang optimal. Sebaliknya tanpa hal itu, apapun yang yang dilakukan guru tidak akan mendapat respon siswa secara aktif. Untuk itu seyogyanya guru memiliki kemampuan dalam memilih dan sekaligus menggunakan metode mengajar yang tepat.

Dalam proses belajar mengajar, guru mempunyai tugas untuk mendorong, membimbing dan memberikan fasilitas belajar bagi peserta didik untuk mencapai tujuan yang diinginkan, yaitu hasil belajar yang memuaskan. Guru juga mempunyai tanggung jawab dalam melihat segala sesuatu yang terjadi didalam kelas dan membantu proses perkembangan siswa. Secara rinci tugas guru berpusat pada:

1. Mendidik anak dengan titik berat memberikan arah dan motivasi dalam pencapaian tujuan, baik jangka pendek maupun jangka panjang.

2. Memberikan fasilitas pencapaian tujuan melalui pengalaman belajar yang memadai.

3. Membantu perkembangan aspek-aspek pribadi, seperti sikap, nilai-nilai dan penyesuaian diri. Demikian pula dalam proses belajar mengajar guru tidak terbatas sebagai penyampai ilmu pengetahuan, akan tetapi lebih dari itu. dia bertanggung jawab atas keseluruhan perkembangan kepribadian murid-muridnya.

Abu Ahmadi $(2004 ; 104)$ mengatakan bahwa: Guru harus menciptakan proses belajar yang menarik, sehingga dapat merangsang murid untuk belajar secara aktif dan dinamis dalam memenuhi kebutuhan dan untuk mencapai tujuan.

Guru sebagai faktor penting dalam mendorong keberhasilan peserta didiknya, harus mempunyai cara atau metode pembelajaran yang bagus. Karena jika tidak, akan menyebabkan kejenuhan didalam proses belajar mengajar. Proses belajar mengajar akan bersifat monoton 
sehingga siswa tidak tertarik dan akan merasa bosan. Akibatnya prestasi belajar siswa akan menurun.

Model pembelajaran sebagai salah satu komponen pendidikan turut menentukan keberhasilan proses pembelajaran. Penerapan metode pembelajaran disesuaikan dengan latar belakang tertentu, misalnya kemampuan guru, kebiasaan guru dan peserta didik, keterbatasan peralatan, kesiapan peserta didik dalam belajar dan sebagainya. Guru harus merancang metode atau teknik tertentu pada saat menyusun perencanaan pembelajaran dan menggunakannya didalam proses belajar mengajar didalam kelas. Karena setiap satuan pembelajaran harus menggambarkan prosedur yang mengacu pada sejumlah metode dan teknik yang terencana dan sistematis untuk mengupayakan pencapaian tujuan pembelajaran.

Penerapan model pembelajaran dengan menggunakan metode atau teknik tersebut, berlaku untuk semua guru, terutama guru bahasa Inggris. Karena bahasa Inggris adalah salah satu materi belajar yang sangat sulit. Dan kebanyakan siswa tidak menyukai materi belajar yang satu ini. Banyak hal yang menyebabkan siswa tidak menyukai belajar bahasa Inggris, seperti: guru yang tidak mempunyai kemampuan yang cukup dalam menyampaikan pelajaran ini dengan baik. Guru yang tidak menggunakan teknik atau cara yang tepat dan sesuai dengan kondisi kelas atau siswanya, sehingga siswa tidak dapat menerima pelajaran bahasa Inggris dengan baik. Dan juga siswa akan cepat merasa bosan sehingga dapat mengakibatkan timbulnya rasa empati terhadap pelajaran bahasa Inggris.

Untuk memperoleh tujuan yang maksimal dalam pembelajaran bahasa Inggris, diperlukan metode mengajar yang baik, yaitu salah satunya dengan menggunakan metode belajar mengajar kontekstual (Contextual Teaching and Learning). Metode kontekstual merupakan konsep belajar yang yang membantu siswa dan guru mengaitkan meteri yang diajarkan dengan situasi dunia nyata. Teknik ini juga dapat mendorong siswa untuk membuat hubungan antara pengetahuan yang dimilikinya dan menerapkannya dalam kehidupan seharihari. Metode CTL menggunakan teknik pembelajaran seperti Direct Instruction, Cooperatif Learning, Questioning, dan Problem Basic Instruction Learning Strategy. Dalam teknik tersebut, pemilihan metode mengajar yang dilakukan oleh seorang guru akan selalu mengaitkan antara materi yang diajarkan dengan situasi dunia nyata

Selain itu, keberhasilan belajar juga dipengaruhi oleh semangat siswa dalam menghadapi pelajaran. Hal ini penting mengingat karakteristik materi pembelajaran yang sangat berbeda satu dengan yang lainnya, sehingga dibutuhkan sebuah motivasi belajar untuk siswa sehingga dapat mendorongnya untuk lebih semangat dalam belajar, seperti yang dikemukakan oleh Hamzah (2007:27) Motivasi pada dasarnya dapat membantu dalam memahami dan menjelaskan perilaku individu yang sedang belajar, antara lain dalam:

1. Menentukan hal-hal yang dapat dijadikan penguat belajar.

2. Memperjelas tujuan belajar yang hendak dicapai.

3. Menentukan ragam kendali terhadap rangsangan belajar.

4. Menentukan ketekunan belajar.

Dalam kegiatan pendidikan, dua aspek motivasi harus dimiliki oleh peserta didik, yaitu motivasi internal dan motivasi eksternal. Adanya motivasi internal (intrinsik) berarti bahwa peserta didik menyadari kegiatan pendidikan yang sedang diikutinya bermanfaat baginya, karena sejalan dengan dengan kebutuhannya. Berkenaan dengan hal tersebut, maka motivasi dalam belajar berfungsi mendorong, mengarahkan dan menggerakkan aktifitas belajar siswa. 


\section{B. RUMUSAN MASALAH}

Berdasarkan uraian latar belakang diatas, maka saya merumuskan permasalahan penelitian sebagai berikut:

1. Adakah pengaruh metode pembelajaran terhadap hasil belajar bahasa Inggris pada siswa SMK Negeri Tangerang?

2. Adakah pengaruh motivasi belajar terhadap hasil belajar bahasa Inggris pada siswa SMK Negeri Tangerang?

3. Adakah pengaruh interaktif metode pembelajaran dan motivasi belajar terhadap hasil belajar bahasa Inggris pada siswa SMK Negeri Tangerang?

\section{METODE PENELITIAN}

Jenis penelitian ini adalah penelitian eksperimen, karena dalam penelitian ini terdapat perlakuan eksperimen dengan membentuk dua kelompok yang terdiri atas satu kelompok kelas eksperimen dan satu kelompok kelas kontrol sebagai pembanding. Pada kelas kontrol diberikan perlakuan metode kontekstual Tanya jawab dan kelas eksperimen diberikan perlakuan metode kontekstual konstruktivism.

Dalam melakukan penelitian ini penulis menggunakan desain eksperimen treatment by level dengan rancangan faktorial $2 \times 2$. Penelitian ini terdiri atas dua variable bebas, dan satu variable terikat.Variable bebas pertama adalah metode pembelajaran (A) sebagai variabel perlakuan, sedangkan variabel bebas kedua adalah motivasi belajar (B) sebagai variable atribut.Variable terikat adalah Hasil Belajar siswa (Y).

Variabel metode pembelajaran (A) terdiri atas metode pembelajaran konstruktivisme(A_1) untuk kelompok eksperimen, dan metode pembelajaran Tanya jawab(A_2 ) untuk kelompok kontrol. Variabel atribut motivasi belajar (B) dibedakan menjadi dua tingkat, yaitu motivasi belajar tinggi(B_1) dan motivasi belajar rendah (B_2).

Adapun desain penelitiannya dapat dilihat pada tabel berikut:

Tabel: Desain faktorial 2 x 2 untuk variabel metode pembelajaran dan Motivasi belajar

\begin{tabular}{|l|l|l|l|}
\hline Motivasi & $\begin{array}{l}\text { Konstruktivisme } \\
\left(A_{1}\right)\end{array}$ & $\begin{array}{l}\text { Tanya } \\
\text { jawab } \\
\left(A_{2}\right)\end{array}$ & JUMLAH \\
\hline Tinggi $\left(B_{1}\right)$ & $A_{1} B_{1}$ & $A_{2} B_{1}$ & $B_{1}$ \\
\hline Rendah $\left(B_{2}\right)$ & $A_{1} B_{2}$ & $A_{2} B_{2}$ & $B_{2}$ \\
\hline JUMLAH & $A_{1}$ & $A_{2}$ & Total $=A \times B$ \\
\hline
\end{tabular}

Keterangan:

A_1 B_1 : Nilai pelajaran bahasa Inggris siswa yang mempunyai motivasi tinggi yang diperlakukan dengan menggunakan konstruktivisme.

A_2 B_1 : Nilai pelajaran bahasa Inggris siswa yang mempunyai motivasi tinggi yang diperlakukan dengan menggunakan Tanya jawab.

A1B2 : Nilai Pelajaran bahasa Inggris siswa yang mempunyai motivasi yang rendah yang diperlakukan dengan menggunakan konstruktivisme. 
A2B2 : Nilai Pelajaran bahasa Inggris siswa yang menggunakan motivasi yang rendah yang diperlakukan dengan menggunakan Tanya jawab.

B1 : Nilai pelajaran bahasa Inggris siswa yang mempunyai motivasi tinggi.

B2 : Nilai pelajaran bahasa Inggris siswa yang mempunyai motivasi rendah.

A1 : Nilai pelajaran bahasa Inggris siswa yang diperlakukan dengan menggunakan konstruktivisme.

A2 : Nilai pelajaran bahasa Inggris siswa yang diperlakukan dengan menggunakan Tanya jawab.

$\mathrm{A} \times \mathrm{B}$ : Nilai pelajaran bahasa Inggris siswa secara keseluruhan.

\section{LANDASAN TEORI}

Secara umum istilah model diartikan sebagai kerangka konseptual yang digunakan sebagai pedoman dalam melakukan suatu kegiatan. Udin S. Winataputra (1994: 34) menyatakan bahwa "Model yang dimaksud dalam model belajar mengajar adalah konsep kerangka yang melukiskan prosedur yang berfungsi sebagai pedoman bagi perancang pengajaran dan para guru dalam merencanakan dan melaksanakan aktifitas belajar mengajar". Dengan demikian aktifitas belajar mengajar merupakan kegiatan yang tertata secara sistematis.

\section{Metode Kontekstual}

Tentang makna kontekstual, Syaiful Sagala (2006: 87) menyatakan sebagai berikut "Kontekstual adalah konsep belajar yang selalu mengaitkan antara materi yang diajarkan dengan situasi dunia nyata dan mendorong siswa membuat hubungan antara pengetahuan yang dimilikinya dengan penerapan dalam kehidupan mereka sehari-hari”.

Belajar dalam kontekstual bukan hanya sekedar mendengarkan dan mencatat, tetapi belajar adalah proses pengalaman secara langsung, Melalui pengalaman itu diharapkan perkembangan siswa terjadi secara utuh, yang meliputi aspek kognitif, afektif dan psikomotorik.

Pembelajaran kontekstual merupakan suatu konsep yang didukung oleh berbagai penelitian actual dalam ilmu kognitif (cognitive science) dan teori-teori tentang tingkah laku (behavior theories) yang secara bersama-sama mendasari konsepsi dan proses pembelajaran kontekstual. Pendekatan ini menilai bahwa secara alami pikiran akan mencari makna sesuai dengan situasi nyata lingkungan seseorang, dan itu dapat terjadi melalui pencarian hubungan yang masuk akal dan bermanfaat. Pemaduan materi pelajaran dengan konteks keseharian siswa didalam pembelajaran kontekstual menghasilkan dasardasar pengetahuan yang mendalam, sehingga siswa kaya dengan pemahaman masalah dan dapat mencari cara untuk menyelesaikannya. Siswa akan mampu secara bebas menggunakan pengetahuannya untuk menyelesaikan masalah-masalah baru yang belum pernah dihadapi serta memiliki tanggung jawab belajar seiring dengan peningkatan pengalaman dan pengetahuan mereka. 
Metode kontekstual adalah teknik belajar yang mengakui dan menunjukkan kondisi alamiah dari pengetahuan. Melalui hubungan didalam dan diluar kelas suatu pendekatan pembelajaran kontekstual menjadikan pengalaman lebih relevan dan berarti bagi siswa dalam membangun pengetahuan yang akan mereka terapkan dalam pembelajaran seumur hidup. Pembelajaran kontekstual menyajikan suatu konsep yang mengaitkan materi pelajaran yang dipelajari siswa dengan konteks materi yang digunakan, serta berhubungan dengan cara belajar siswa. Konteks yang memberikan arti, relevansi dan manfaat penuh terhadap hasil belajar. Seperti yang diungkapkan Wina Sanjaya (1995: 25) bahwa: "Model pembelajaran kontekstual adalah suatu model pembelajaran yang menekankan kepada proses keterlibatan siswa secara penuh untuk menemukan materi yang dipelajari dan menghubungkannya dengan situasi kehidupan nyata".

Menurut Wina S (1995: 25) terdapat tiga hal yang harus dipahami dalam model pembelajaran kontekstual yaitu:

a.Menekankan pada proses keterlibatan siswa untuk menemukan materi, artinya proses belajar diorientasikan pada proses pengalaman secara langsung.

b. Mendorong agar siswa dapat menemukan hubungan antara materi yang dipelajari dengan situasi kehidupan nyata sehingga tidak mudah dilupakan.

c.Mendorong siswa untuk dapat menerapkan materipelajaran dalam kehidupan seharihari, sehingga dapat mewarnaai perilakunya.

Lebih lanjut Wina S. (1995:26) menjelaskan lima karakteristik penting dalam proses pembelajaran kontekstual. Kelima karakteristik itu adalah sebagai berikut:

a. Dalam model pembelajaran kontekstual, pembelajaran merupakan prosespengaktifan pengetahuan dan pengalaman yang sudah ada pada diri siswa. Artinya, materi yang akan dipelajari tidak terlepas dari pengetahuan dan pengalaman yang sudah dipelajari siswa sebelumnya. Dengan demikian pengetahuan yang akan diperoleh siswa adalah pengetahuan yang utuh yang memiliki keterkaitan satu sama lain.

b. Pembelajaran yang kontekstual adalah belajar dalam rangka memperoleh dan menambah pengetahuan baru (acquiring knowledge). Pengetahuan baru ini diperoleh dengan cara deduktif, artinya pembelajaran dimulai dengan mempelajari keseluruhan, kemudian memperhatikan detailnya.

c. Pemahaman pengetahuan (Understanding knowledge), artinya pengetahuan yang diperoleh bukan untuk dihapal tetapi untuk dipahami dan diyakini, misalnya dengan cara meminta tanggapan dari yang lain tentang pengetahuan yang diperolehnya dan berdasarkan tanggapan tersebut baru pengetahuan itu dikembangkan.

d. Mempraktikan pengetahuan dan pengalaman tersebut (applying knowledge), artinya pengetahuan dan pengalaman yang diperolehnya harus dapat diaplikasikan dalam kehidupan siswa.

e. Melakukan refleksi (Reflecting knowledge) terhadap strategi pengembangan pengetahuan. Hal ini dilakukan sebagai umpan balik untuk proses perbaikan dan penyempurnaan strategi.

Belajar akan lebih bermakna jika anak mengalami apa yang dipelajarinya, bukan mengetahuinya. Pembelajaran yang berorientasi target penguasaan materi terbukti berhasil dalam kompetisi mengingat dalam jangka pendek, tetapi gagal dalam membekali anak memecahkan masalah dalam kehidupan jangka panjang. Pembelajaran kontekstual sangatlah diperlukan untuk memberdayakan siswa melalui landasan kontruktivisme. Pembelajran kontekstual dapat dijadikan alternative model pembelajaran yang baru dan diharapkan dapat membantu siswa belajar melalui pengalaman, bukan hapalan. 
Pengetahuan bukanlah seperangkat fakta dan konsep yang siap diterima, akan tetapi sesuatu yang harus dikonstruksi sendiri oleh siswa.

Ciri-ciri metode pembelajaran kontekstual: Konstruktif, Tanya jawab, Menemukan, Masyarakat belajar, Pemodelan, Refleksi, Penilaiaan sebenarnya

Pembelajaran kontekstual merupakan suatu konsep yang didukung oleh berbagai penelitian aktual dalm ilmu kognitif (cognitive science) dan teori-teori tentang tingkah laku (behavior theories) yang secara bersama-sama mendasari konsepsi dalam proses belajar kontekstual. Pemaduan materi pelajaran dengan konteks keseharian siswa didalam pembelajaran kontekstual akan menghasilkan dasar-dasar pengetahuan yang mendalam dimana siswa kaya akan pemahaman masalah dan cara menyelesaikan masalah-masalah serta memiliki tanggung jawab terhadap belajarnya seiring dengan peningkatan pengalaman pengetahuan baru yang belum pernah dihadapi.

Pemanfaatan pembelajaran kentekstual akan menciptakan peserta aktif bukan hanya pengamat yang pasif dan bertanggung jawab terhadap hasil belajarnya. Penerapan pembelajaran kontekstual sangat membantu guru untuk menghubungkan materi pelajaran dengan situasi dunia nyata dalam mengajar.

Dalam metode kontekstual terdapat dua pemahaman, yaitu:

1) Konstruktivisme

"Konstruktivisme adalah proses membangun atau menyusun pengetahuan baru dalam struktur kognitif siswa berdasarkan pengalaman”. (Wina Sanjaya, 1995: 28)

Dalam buku lain, Syaiful Sagala (2006: 89) mengatakan, kontekstual dilakukan dengan melibatkan pembelajaran yang efektif, yakni konstruktivisme.

Konstruktivisme merupakan landasan berfikir (filosofis) dari metode kontekstual, yakni pengetahuan dibangun sedikit demi sedikit yang hasilnya diperluas melalui konteks yang terbatas dan tidak dengan tiba-tiba. Pengetahuan bukanlah seperangkat fakta, konsep atau kaidah yang yang siap diambil dan diingat.

Konstruktivisme merupakan pengetahuan yang dibangun oleh manusia sedikit demi sedikit yang hasilnya diperluas dengan konteks yang terbatas (sempit) dan tidak secara tiba-tiba. Didalam pandangan konstruktivisme, strategi pembelajaran lebih diutamakan.

2) Tanya Jawab

Guru dipandang perlu untuk bertanya guna untuk mendorong, membimbing dan menilai kemampuan berfikir siswanya didalam kegitan belajar mengajar. Dengan bertanya jawab juga dapat membuat siswa lebih kreatif dan memiliki rasa ingin tahu yang tinggi. Wina Sanjaya (1995: 42) mengatakan bahwa, "Belajar pada hakikatnya bertanya dan menjawab pertanyaan. Bertanya dapat dipandang sebagai refleksi dari setiap keingintahuan setiap individu, sedangkan menjawab pertanyaan mencerminkan kemampuan seseorang dalam berfikir".

Dalam prose pembelajaran kontekstual, guru tidak menyampaikan informasi begitu saja, tetapi guru juga memancing siswa agar dapat menemukan sendiri informasi yang terdapat dalam materi pelajaran. Karena itu, teknik bertanya sangatlah penting, karena melalui proses tanya jawab tersebut siswa membuat siswa lebih kreatif dalam proses belajar mengajar. 
Kegiatan bertanya dapat di kelompokkan antara siswa dengan siswa, siswa dengan guru, guru dengan siswa atau juga siswa dengan orang lain. Pengetahuan seseorang selalu berawal dari bertanya, oleh karena itu bertanya merupakan strategi utama pembelajaran dalam pendekatan kontekstual. Dalam proses pembelajaran yang produktif kegiatan bertanya berguna untuk:

a) Menggali informasi

b) Mengecek pemahaman siswa

c) Membangkitkan respon siswa

d) Mengetahui sejauh mana keingintahuan siswa pada sesuatu hal

e) Memfokuskan perhatian siswa pada sesuatu yang dikehendaki oleh guru

f) Untuk membangkitkan lebih banyak lagi pertanyaan

g) Untuk menyegarkan kembali pengetahuan siswa pada semua aktifitas belajar

2. Motivasi Belajar

Kata "Motif", diartikan sebagai daya upaya yang mendorong seseorang untuk melakukan sesuatu. Motif dapat dikatakan sebagai daya penggerak dari dalam untuk melakukan aktifitas-aktifitas tertentu demi mencapai suatu tujuan.

Menurut Mc Donald, yang dikutif oleh Oemar Hamalik (2003; 158), "Motivasi adalah perubahan energy dalam diri (pribadi) seseorang yang ditandai dengan timbulnya perasaan dan reaksi untuk mencapai tujuan".

Oemar Hamalik juga mengatakan bahwa terdapat tiga elemen penting terjadinya motivasi, yaitu:

a. Terjadinya perubahan energy pada diri setiap individu manusia, dengan ditandai adanya perubahan energi di dalam sistim "Neurophysiological".

b. Munculnya rasa (feeling), yang berkaitan dengan persoalan-persoalan kejiwaan, afeksi dan emosi yang dapat menentukan tingkah laku manusia.

c. Motivasi akan terjadi karena adanya tujuan, jadi motivasi dalam hal ini sebenarnya merupakan respon dari suatu aksi, yaitu tujuan.

Selanjutnya, Oemar membagi jenis-jenis motivasi menjadi dua bagian, yaitu:

a. Motivasi Intrinsik

Motivasi intrinsik adalah motivasi yang tercakup didalam diri seseorang untuk memenuhi kebutuhan dan tujuan-tujuannya. Motivasi intrinsik adalah motivasi yang hidup dalam diri siswa dan berguna dalam situasi belajar yang fungsional.

b. Motivasi eksttrinsik

Motivasi ekstrinsik dalah motivasi yang disebabkan oleh factor-faktor dari luar situasi belajar, seperti motivasi untuk mendapatkan pujian, hadiah, ijazah dan lain sebagainya.

Ada beberapa pendapat yang berbeda tentang definisi motivasi. Berikut ini adalah beberapa pendapat para ahli tentang definisi motivasi:

Soemanto (1998: 205) mengatakan bahwa "Motivasi adalah kondisi atau keadaan yang memberikan dorongan kepada seseorang untuk bertingkah laku dalam mencapai tujuan yang ditimbulkan oleh motivasi tersebut". 
Purwanto (1990: 60) berpendapat bahwa "Motivasi ialah segala sesuatu yang mendorong seseorang untuk bertindak melakukan sesuatu".

Nashar (2006: 2) berpendapat bahwa, motivasi adalah dorongan usaha yang disadari untuk mempengaruhi tingkah laku seseorang agar ia tergerak hatinya untuk melakuakan sesuatu sehingga mencapai hasil atau tujuan tertentu.

Motivasi memiliki dua komponen, yaitu komponen dalam (inner component) dan komponen luar (outer component).

Komponen dalam ialah perubahan dalam diri seseorang, keadaan merasa tidak puas, dan ketegangan psikologis. Komponen luar ialah apa yang diinginkan seseorang, tujuan yang menjadi arah kelakuannya. "Komponen dalam ialah kebutuhan-kebutuhan yang ingin dipuaskan, sedangkan komponen luar ialah tujuan yang hendak dicapai". Oemar Hamalik, (2005: 159).

Dalam kegiatan belajar, motivasi dapat dikatakan sebagai "keseluruhan" daya penggerak didalam diri siswa yang nenimbulkan kegiatan dalam, sehingga tujuan yang dikehendaki oleh subyek belajar dapat tercapai. Dikatakan keseluruhan karena ada beberapa motif yang secara bersama-sama menggerakan siswa untuk belajar.

Motivasi belajar merupakan faktor psikis yang bersifat non-intelektual. Peranannya yang khas adalah dalam perubahangairah, merasa senang dan bersemangat untuk belajar. Siswa yang memiliki motivasi yang kuat, akan banyak mempunyai energy untuk kegiatan belajar. Seorang siswa akan berhasil dalam belajar, jika pada dirinya terdapat keinginan untuk belajar. Hubungan antara keinginan untuk belajar dengan hasil belajar cenderung bersifat positif, artinya baik tidaknya hasil belajar seseorang dipengaruhi oleh seberapa besar keinginan belajar siswa tersebut. Semakin besar keinginan untuk belajar, maka akan semakin baik pula hasil belajarnya. Sardiman (2000: 38) berpendapat bahwa: "Hubungan antara keinginan dan hasil belajar dipandang sebagai prinsip dan hokum pertama dalam dalam kegiatan belajar mengajar". Keinginan, hasrat atau dorongan untuk belajar tersebut lebih popular disebut dengan istilah motif atau motivasi

Dari uraian diatas diperoleh gambaran, bahwa motivasi merupakan mesin penggerak, baik dari dalam (internal) maupun dari luar individu (eksternal), yang dapat menggerakkan individu untuk melakukan sesuatu dalam rangka mencapai tujuan tertentu. Dengan "motivasi" seseorang dapat mencapai prestasi yang gemilang pada hasil belajarnya.

Abu Hamadi (2004: 106) menyatakan bahwa "Tinggi rendahnya prestasi belajar banyak ditentukan oleh tinggi rendahnya motif berprestasi”. Dalam hal ini, guru berperan sebagai motivator didalam keseluruhan kegiatan belajar mengajar.

Ada empat hal yang dapat dikerjakan guru dalam memberikan motivasi, yaitu:

1) Membangkitkan dorongan kepada siswa untuk belajar

2) Menjelaskan secara konkret kepada siswa apa yang dapat dilakukan pada akhir pengajaran

3) Memberikan ganjaran terhadap prestasi yang dicapai sehingga dapat merangsang untuk mencapai prestasi yang lebih baik dikemudian hari

4) Membentuk kebiasaan belajar yang baik

Dalam kegiatan pendidikan, dua aspek motivasi harus dimiliki oleh peserta didik, yaitu motivasi internal dan motivasi eksternal. Adanya motivasi internal (intrinsik) berarti 
bahwa peserta didik menyadari kegiatan pendidikan yang sedang diikutinya bermanfaat baginya, karena sejalan dengan dengan kebutuhannya. Berkenaan dengan hal tersebu, maka motivasi dalam belajar berfungsi mendorong, mengarahkan dan menggerakkan aktifitas belajar siswa.

Soemanto (1987: 205) mengatakan bahwa "belajar sebagai proses'Trial and error'. Belajar dengan 'trial and error' itu dimulai dengan adanya beberapa motif yang mendorong keaktifan". Dengan demikian untuk mengaktifkan anak dalam belajar diperlukan motivasi.

Selanjutnya ia mengatakan bahwa, motivasi dapat merubah semngat diri seseorang yang ditandai dengan dorongan efektif dan reaksi-reaksi untuk mencapai tujuan. Motivasi merupakan bagian dari proses belajar. Soemanto (1987: 206)

Teori lain tentang motivasi ialah teori fisiologis, Sardiman (2000: 80), berpendapat bahwa semua tindakan manusia berakar pada usaha untuk memenuhi kepuasan dan kebutuhan organic atau kebutuhan untuk kepentingan fisik. Dengan kata lain dapat disebut sebagai kebutuhan primer, seperti kebutuhan akan makanan, minuman dan dan lain-lain. Teori Fisiologis ini disebut juga behavior theory.

Motivasi ditandai dengan munculnya 'feeling' seseorang. Dalam hal ini motivasi relevan dengan persoalan-persoalan kejiwaan, afeksi dan emosi yang dapat menentukan tingkah laku manusia. Motivasi akan dirangsang karena adanya tujuan. Motivasi sebenarnya merupakan respon dari suatu aksi yaitu tujuan. Motivasi memang muncul dalam diri manusia, tetapi kemunculannya karena adanya unsur lain yaitu tujuan. Tujuan ini akan menyangkut masalah kebutuhan.

Purwanto (1990: 78), berpendapat bahwa manusia mempunyai lima tingkatan kebutuhan pokok. Kelima tingkatan kebutuhan pokok inilah yang kemudian dijadikan kunci dalam mempelajari motivasi manusia.

Adapun kelima tingkat kebutuhan pokok yang dimaksud adalah:

1) Kebutuhan fisiologis, merupakan kebutuhan dasar (primer) dan vital, yang menyangkut fungsi-fungsi biologis dasar dan organism manusia, seperti pangan, sandang, papan, kesehatan fisik, kebutuhan seks dll.

2) Kebutuhan rasa aman dan perlindungan (safety and security) seperti terjamin keamanannya, terlindung dari bahaya dan ancaman penyakit, perang, kemiskinan, kelaparan, perlakuan tidak adil dan sebagainya.

3) Kebutuhan social (social need) yang meliputi kebutuhan akan dicintai, diperhitungkan sebagai pribadi, diakui sebagai anggota kelompok, rasa setia kawan, kerjasama.

4) Kebutuhan akan penghargaan (esteem need), termasuk kebutuhan dihargai karena prestasi, kemampuan, kedudukan atau status, pangkat dsb.

5) Kebutuhan akan aktualisasi diri (self actualization), seperti mempertinggi potensi-potensi yang dimiliki, pengembangan diri secara maksimum, kreatifitas, dan ekspresi diri.

Dalam proses belajar mengajar pada dasarnya merupakan proses yang terjadi antara siswa dan guru, antara yang belajar dan mengajar, atau antara pembelajar dengan yang member pelajaran. Melalui proses pembelajaran ini akan berkembang secara sempurna atau 
tercapai hasil yang optimal bila guru dan siswa terlibat aktif dan mempunyai motivasi yang tinggi.

\section{HASIL DAN PEMBAHASAN}

\section{Uji Hipotesis}

Setelah dilakukan uji normalitas dan homogenitas dan hasilnya menunjukkan bahwa sampel penelitian berasal dari populasi distribusi normal dan varians sampel homogeny, maka pengujian hipotesis dengan menggunakan ANOVA dapat dilakukan.

Analisis terhadap data hasil belajar siswa dilakukan dengan menggunakan ANOVA dua arah yang pekerjaan rumahocess perhitungannya di bantu dengan pekerjaan rumahogram SPSS 20. Hasil uji ANOVA tersebut kemudian dilanjutkan dengan uji F untuk mengetahui signifikansi perbedaan diantara masing-masing kelompok secara signifikan (simple effect). Dengan kata lain, uji F digunakan dengan tujuan untuk melihat kelompok sampel mana yang lebih tinggi hasil belajar bahasa Inggris siswa ditinjau dari motivasi belajar.

Ringkasan hasil analisis data dengan menggunakan ANOVA dapat dilihat pada table berikut:

Tabel 4.12. Uji Hipotesis Penelitian

\begin{tabular}{|c|c|c|c|c|c|}
\hline \multicolumn{6}{|c|}{ Tests of Between-Subjects Effects } \\
\hline \multicolumn{6}{|c|}{ Dependent Variable: Hasil Belajar Bahasa Inggris } \\
\hline Source & \begin{tabular}{|ll} 
Type & III \\
Sum & of \\
Squares &
\end{tabular} & Df & \begin{tabular}{|l} 
Mean \\
Square
\end{tabular} & $\mathrm{F}$ & Sig. \\
\hline $\begin{array}{l}\text { Corrected } \\
\text { Model }\end{array}$ & $4856,250^{\mathrm{a}}$ & 3 & 1618,750 & 25,632 & ,000 \\
\hline Intercept & $\begin{array}{l}\text { 440748,05 } \\
\text { 0 }\end{array}$ & 1 & $\begin{array}{l}440748,05 \\
0\end{array}$ & $\begin{array}{l}6978,9 \\
47\end{array}$ &, 000 \\
\hline A & 1805,000 & 1 & 1805,000 & 28,581 & ,000 \\
\hline $\mathrm{B}$ & 2784,800 & 1 & 2784,800 & 44,095 &, 000 \\
\hline $\mathrm{A} * \mathrm{~B}$ & 266,450 & 1 & 266,450 & 4,219 &, 043 \\
\hline Error & 4799,700 & 76 & 63,154 & & \\
\hline Total & $\begin{array}{l}450404,00 \\
0\end{array}$ & 80 & & & \\
\hline $\begin{array}{l}\text { Corrected } \\
\text { Total }\end{array}$ & 9655,950 & 79 & & & \\
\hline
\end{tabular}

Berdasarkan data di atas, maka hipotesis penelitian yang diajukan dapat terjawab. Adapun penjelasan mengenai table di atas adalah sebagai berikut:

1. Hipotesis Pertama: terdapat pengaruh yang signifikan motode pembelajaran terhadap hasil belajar bahasa Inggris siswa di SMK Negeri Tangerang .

Berdasarkan table 4.12 diperoleh hasil Anova dengan nilai Fo $=28,581$ dan Sig. $=0,000<$ 0,05, maka hipotesis nol (Ho) ditolak dan hipotesis alternative (H1) diterima. Hal ini memiliki arti bahwa terdapat pengaruh yang signifikan penggunaan motode pembelajaran terhadap hasil belajar bahasa Inggris siswa di SMK Negeri Tangerang, atau dengan kata 
lain, terdapat perbedaan hasil belajar bahasa Inggris siswa yang menggunakan metode pembelajaran konstruktivisme dengan yang menggunakan metode pembelajaran tanya jawab.

2. Hipotesis Kedua: terdapat pengaruh yang signifikan motivasi belajar terhadap hasil belajar bahasa Inggris siswa di SMK Negeri Tangerang.

Berdasarkan table 4.12 diperoleh hasil Anova dengan nilai Fo = 44,095 dan Sig. = 0,000 < 0,05, maka hipotesis nol (Ho) ditolak dan hipotesis alternative (H1) diterima. Hal ini memiliki arti bahwa terdapat pengaruh yang signifikan motivasi belajar terhadap hasil belajar bahasa Inggris siswa di SMK Negeri Tangerang. Atau dengan kata lain, terdapat perbedaan hasil belajar bahasa Inggris siswa yang memiliki motivasi belajar tinggi dengan yang memiliki motivasi belajar rendah.

3. Hipotesis Ketiga: terdapat pengaruh interaksi yang signifikan motode pembelajaran dan motivasi belajar terhadap hasil belajar bahasa Inggris siswa di SMK Negeri di Tangerang.

Berdasarkan table 4.12 diperoleh hasil Anova dengan nilai Fo = 4,219 dan Sig. = 0,043 < 0,05, maka hipotesis nol (Ho) ditolak dan hipotesis alternative (H1) diterima. Hal ini memiliki arti bahwa terdapat pengaruh interaksi yang signifikan motode pembelajaran dan motivasi belajar terhadap hasil belajar bahasa Inggris siswa siswa di SMK Negeri Tangerang .

Sementara itu, nilai Adjusted R. Squared sebesar 0,503 memiliki arti bahwa hasil belajar bahasa Inggris siswa yang menggunakan motode pembelajaran dan motivasi belajar memberikan pengaruh sebesar 50,1\% terhadap peningkatan hasil belajar bahasa Inggris siswa di SMK Negeri Tangerang .

\section{Uji Lanjut}

Sehubungan dengan terjadinya interaksi yang signifikan penggunaan motode pembelajaran dengan motivasi belajar terhadap hasil belajar bahasa Inggris siswa, maka diperlukan uji lanjutan. Adapun uji lanjutan yang dipakai adalah uji Tukey.

Tabel 4.13. Uji Hipotesis Penelitian

\begin{tabular}{|c|c|c|c|c|c|c|}
\hline \multicolumn{7}{|c|}{ Multiple Comparisons } \\
\hline \multicolumn{7}{|c|}{$\begin{array}{l}\text { Dependent Variable: Hasil Belajar Bahasa Inggris } \\
\text { Tukey HSD }\end{array}$} \\
\hline \multirow[t]{2}{*}{$\begin{array}{ll}\text { (I) } & \text { Pos } \\
\text { Hoc } & \end{array}$} & \multirow[t]{2}{*}{$\begin{array}{ll}\text { (J) } & \text { Pos } \\
\text { Hoc } & \end{array}$} & \multirow{2}{*}{\begin{tabular}{|l} 
Mean \\
Difference \\
$(\mathrm{I}-\mathrm{J})$
\end{tabular}} & \multirow[t]{2}{*}{\begin{tabular}{|l} 
Std. \\
Error
\end{tabular}} & \multirow[t]{2}{*}{ Sig. } & \multicolumn{2}{|l|}{$\begin{array}{l}95 \% \\
\text { Interval }\end{array}$} \\
\hline & & & & & $\begin{array}{l}\text { Lower } \\
\text { Bound }\end{array}$ & $\begin{array}{l}\text { Upper } \\
\text { Bound }\end{array}$ \\
\hline \multirow[t]{4}{*}{ A1B1 } & A1B1 & & & & & \\
\hline & A1B2 & $15,45^{*}$ & 2,513 & ,000 & 8,85 & 22,05 \\
\hline & $\mathrm{A} 2 \mathrm{~B} 1$ & $13,15^{*}$ & 2,513 & ,000 & 6,55 & 19,75 \\
\hline & A2B2 & $21,30^{*}$ & 2,513 &, 000 & 14,70 & 27,90 \\
\hline \multirow[t]{4}{*}{ A1B2 } & A1B1 & $-15,45^{*}$ & 2,513 &, 000 & $-22,05$ & $-8,85$ \\
\hline & A1B2 & & & & & \\
\hline & A2B1 & $-2,30$ & 2,513 & ,797 & $-8,90$ & 4,30 \\
\hline & $\mathrm{A} 2 \mathrm{~B} 2$ & 5,85 & 2,513 & ,101 &,- 75 & 12,45 \\
\hline \multirow[t]{2}{*}{$\mathrm{A} 2 \mathrm{~B} 1$} & A1B1 & $-13,15^{*}$ & 2,513 &, 000 & $-19,75$ & $-6,55$ \\
\hline & A1B2 & 2,30 & 2,513 & ,797 & $-4,30$ & 8,90 \\
\hline
\end{tabular}




\begin{tabular}{|l|l|l|l|l|l|l|}
\hline \multirow{5}{*}{} & A2B1 & & & & & \\
\hline & A2B2 & $\mathbf{8 , 1 5}$ & $\mathbf{2 , 5 1 3}$ & $\mathbf{, 0 0 9}$ & $\mathbf{1 , 5 5}$ & $\mathbf{1 4 , 7 5}$ \\
\hline A2B2 & A1B1 & $\mathbf{- 2 1 , 3 0}$ & $\mathbf{2 , 5 1 3}$ & $\mathbf{, 0 0 0}$ & $\mathbf{- 2 7 , 9 0}$ & $\mathbf{- 1 4 , 7 0}$ \\
\hline & A1B2 & $\mathbf{- 5 , 8 5}$ & $\mathbf{2 , 5 1 3}$ & $\mathbf{1 0 1}$ & $\mathbf{- 1 2 , 4 5}$ & $\mathbf{7 5}$ \\
\hline & A2B1 & $\mathbf{- 8 , 1 5}$ & $\mathbf{2 , 5 1 3}$ & $\mathbf{0 0 9}$ & $\mathbf{- 1 4 , 7 5}$ & $\mathbf{- 1 , 5 5}$ \\
\hline & A2B2 & & & & \\
\hline
\end{tabular}

Berdasarkan uji lanjut di atas, dapat disimpulkan sebagai berikut:

1. Pada kelompok A1B1 dan A1B2 terlihat bahwa Mean Difference sebesar 15,45, artinya selisih antara rata-rata kelompok A1B1 dan A1B2 sebesar 15,45. Nilai ini cukup besar dan dapat dibuktikan dengan nilai signifikansi $0,000<0,05$, atau dapat diartikan bahwa kelompok A1B1 dan A1B2 berbeda secara signifikan.

2. Pada kelompok A1B1 dan A2B1 terlihat bahwa Mean Difference sebesar 13,15, artinya selisih antara rata-rata kelompok A1B1 dan A2B1 sebesar 13,15. Nilai ini cukup besar dan dapat dibuktikan dengan nilai signifikansi $0,000<0,05$, atau dapat diartikan bahwa kelompok A1B1 dan A2B1 berbeda secara signifikan.

3. Pada kelompok A1B1 dan A2B2 terlihat bahwa Mean Difference sebesar 21,30, artinya selisih antara rata-rata kelompok A1B1 dan A2B2 sebesar 21,30. Nilai ini cukup besar dan dapat dibuktikan dengan nilai signifikansi $0,000<0,05$, atau dapat diartikan bahwa kelompok A1B1 dan A2B2 berbeda secara signifikan.

4. Pada kelompok A1B2 dan A2B1 terlihat bahwa Mean Difference sebesar -2,3, artinya selisih antara rata-rata kelompok A1B2 dan A2B1 sebesar -2,3. Nilai ini cukup kecil dan dapat dibuktikan dengan nilai signifikansi 0,797>0,05, atau dapat diartikan bahwa kelompok A1B2 dan A2B1 tidak berbeda secara signifikan

5. Pada kelompok A1B2 dan A2B2 terlihat bahwa Mean Difference sebesar 5,85, artinya selisih antara rata-rata kelompok A1B2 dan A2B2 sebesar -5,85. Nilai ini cukup kecil dan dapat dibuktikan dengan nilai signifikansi $0,101>0,05$, atau dapat diartikan bahwa kelompok A1B2 dan A2B2tidak berbeda secara signifikan.

6. Pada kelompok A2B2 dan A2B1 terlihat bahwa Mean Difference sebesar 8,15, artinya selisih antara rata-rata kelompok A2B2 dan A2B1 sebesar -8,15. Nilai ini cukup besar dan dapat dibuktikan dengan nilai signifikansi $0,009<0,05$, atau dapat diartikan bahwa kelompok A2B2 dan A2B1 berbeda secara signifikan.

\section{DAFTAR PUSTAKA}

[1] Arikunto Suharsini, Prosedur Penelitian Pendekatan Praktik, Jakarta: Rineka Cipta, 1996

[2] Abu Ahmadi, Psikologi Belajar, Jakarta, Rineka Cipta, 2004

[3] Asri Budiningsih, Belajar dan Pembelajaran, Jakarta, Rineka Cipta, 1995

[4] Ainurrahman, Belajar dan Pembelajaran, Bandung, Alfa Beta, 2009

[5] Aqib, Zainal, Professionalisme Guru dalam Pembelajaran, Jakarta Insan Cendikia, 200

[6] Hamzzah B. Uno, Teori Motivasi dan Pengukurannya, Jakarta, Bumi Aksara, 2007

[7] Mustaji Sugiarto, Pembelajaran Berbasis Konstruktivistik, Universitas Surabaya, 2005

[8] Mohamad Nazir, Metode Penelitian, Ghalia Indonesia, 1999

[9] Margono S, Metodologi Pendidikan, Rineka Cipta, 2004 
[10] Nashar, Peranan Motivasi dan Kemampuan Awal, Delia Press, 2006

[11] Oemar Hamalik, Proses Belajar Mengajar, Bumi Aksara, 2005

[12] Purwanto Ngalim, Psikologi Pendidikan, Bandung, Remaja Rosda Karya, 1990

[13] Sardiman, Interaksi dan Motivasi Belajar Mengajar, Jakarta, Raja Grafindo Persada, 2000

[14] Sudijono Anas, Pengantar Evaluasi Pendidikan, Yogyakarta, Rajawali Press 1995

[15] Syaiful Sagala, Konsep dan Makna Pembelajaran, Bandung, Alpa Beta, 2006

[16] Santosa Murwani, Penelitian di Perguruan Tinggi, UHAMKA, 2006

[17] Oemanto Wasty, Psikologi Pendidikan Landasan Keja Pemipin Pendidikan, Jakarta, Rineka Cipta, 1998

[18] Sudikan Seta Yuwono, Pendekatan Kontekstual dalam Pembelajaran Sastra, Surabaya, Unesa, 2004

[19] Sujana Nana, Penelitian Hasil Proses Belajar Mengajar, Bandung, PT Remaja Rosda Karya, 1989

[20] Sugiyono, Metode Penelitian Pendidikan, Bandung, Alfabeta 2008

[21] Sumarna Surapranata, Analisis, Validitas, Reliabilitas, dan Interprestasi Hasil Tes, bandung, PT Remaja Rosda Karya, 1990

[22] Udin S. Winata Putra, Strategi Belajar Mengajar, Jakarta, Depdikbud, 1993

[23] Unindra, Buku Panduan Penulisan Tesis Program Pasca Sarjana, Universitas Indraprasta PGRI, Jakarta, Unindra 2013

[24] Winkel WS. Psikologi Pengajaran, Jakarta, Grasindo, 1991

[25] Wina Sanjaya, Strategi Pembelajara, 1995

[26] Winarno Surachmad, Metodologi Pengajaran Nasional, Bandung, Cemara, 1996 